Int. J. Environ. Res. Public Health 2007, 4(2), 173-184

International Journal of

Environmental Research and Public Health

ISSN 1661-7827

www.ijerph.org

(c) 2007 by MDPI

\title{
Using Remote Sensing and GIS in the Analysis of Ecosystem Decline along the River Niger Basin: The Case of Mali and Niger
}

\author{
Yaw A. Twumasi ${ }^{1}$, and Edmund C. Merem ${ }^{2 *}$ \\ ${ }^{1}$ Center for Hydrology, Soil Climatology and Remote Sensing, Department of Plant and Soil Science, P. O. Box 1208, Alabama \\ A\&M University, Normal, AL 35762, USA \\ ${ }^{2}$ Department of Urban and Regional Planning, Jackson State University, Jackson, MS 39211, USA \\ *Correspondence to Dr. Edmund C. Merem; Email: edmund.c.merem@jsums.edu
}

Received: 06 December 2006 / Accepted: 30 April 2007 / Published: 30 June 2007

\begin{abstract}
In the Sub-Saharan African region of the River Niger Basin, where none of the major rivers is fully contained within the borders of a single nation, riverine ecosystem health monitoring is essential for survival. Even the globally proclaimed goals of sustainability and environmental security in the region are unattainable without using geospatial technologies of remote sensing and Geographic Information Systems (GIS) as conduits for environmental health within shared waters. Yet the systematic study of the nature of cooperation between states over shared water resources in troubled areas of the Middle East continues to dominate the literature with minimal coverage of the SubSaharan Africa experience and the role of GIS and remote sensing in monitoring the problem. Considering the intense ecosystem stress inflicted on River Niger by human activities and natural forces emanating from upstream and downstream nations. Researching the growing potential for acute riverine ecosystem decline among the nations of Niger and Mali along the River Niger Basin with the latest advances in spatial information technology as a decision support tool not only helps in ecosystem recovery and the avoidance of conflicts, but it has the potentials to bring countries much closer through information exchange. While the nature of the problem remains compounded due to the depletion of available water resources and environmental resources within shared waters, the lack of information exchange extracts ecological costs from all players. This is essential as the Niger Basin nations move towards a multinational watershed management as a conduit for sustainability. To confront these problems, some research questions with relevance to the paper have been posed. The questions include, Have there been any declines in the riverine ecosystem of the study area? What are the effects and what factors trigger the changes? What mitigation measures are in place for dealing with the problems? The first objective of the paper is to develop a new framework for analyzing the health of riverine ecosystems while the second objective seeks a contribution to the literature. The third objective is to design a geo-spatial tool for riverine ecosystem management and impact analysis. The fourth objective is to measure the nature of change in riverine environments with the latest advances in geo-spatial information technologies and methods. In terms of methodology, the paper relies on primary data sources analyzed with descriptive statistics, GIS techniques and remote sensing. The sections in the paper consist of a review of the major environmental effects and factors associated with the problem as well as mitigation measures in Mali and Niger. The paper concludes with some recommendations. The results point to growing modification along the riverine environments of the Mali and Niger portions of the River Niger Basin due to a host of factors.
\end{abstract}

Keywords: GIS, remote sensing, riverine ecosystem, management, decline

\section{Introduction}

The analysis of hydropolitics referred to as the politics of water symbolizes the most complex arenas of interactions between states that share river basins [1, 2, 3].
Transboundary water resources use, shaped by hydropolitics, tie up the states sharing a river basin into a web of interdependence from which no one can extricate itself $[1,4]$. The complexity of this arrangement multiplies as nationally available water resources go depleted and 
nations forced to look beyond their own borders to meet the demand for water to satisfy multiple needs $[5,6]$. Under this current of thought, the ecological declines ravaging the Niger basin seem to be neglected. Yet, in the Sub-Saharan African region of the River Niger Basin, where none of the major rivers is fully contained within the borders of a single nation, riverine ecosystem health monitoring along shared waters is essential for survival [7].

Even the globally proclaimed goals of sustainability and environmental security initiated by the authorities in the region are unattainable without using geospatial technologies of remote sensing and Geographic Information Systems (GIS) as conduits for environmental health within shared waters. Notwithstanding, the situation along the Niger Basin, the systematic study of the nature of cooperation between states over shared water resources in the troubled areas of the Middle East continues to dominate the literature with minimal coverage of the SubSaharan Africa experience within the Niger basin and the role of GIS and remote sensing in monitoring the problem. The review of studies for nearly three decades show a vast array of literature focusing solely on the Middle East while overlooking the existence of similar problems in the Sub-Saharan region of the River Niger Basin. In a series of studies focusing on multinational watersheds outside of the West African region, Dinar [4] and Charrier [8] analyzed conflict-resolution and environmental sustainability in the Middle East and North African (MENA) region with little emphasis on the River Niger basin area.

Concerns about the continuous negligence of ecological decline facing the region and the receding water situation in Niger River region prompted moves by African leaders to develop an action plan to encourage the management of the river and prevent its levels from plummeting $[9,10,11]$. While the basin remains threatened by ecological decline, the authorities of the basin led by the Niger Basin Authority (NBA) has been trying to define a shared vision for the sustainable use of the river [12]. Compounding the task of the basin's management is the current population of about 110 million served by the river system. The number of inhabitants served by the basin will double by the year 2020 in an already fragile ecosystem [10]. Other serious concerns with regional implications in the management of the River Niger center on the transboundary flow of toxic effluents emptied from upstream industrial sites and human settlements on the tributaries of the Upper Niger without treatment [13]. Such practices contribute to pollution of the water and spreading of diseases as the river meander downstream [14].

With elevated levels of ecosystem stress rampant in the region [13-15], researching the growing potential for acute riverine ecosystem decline among the nations of Niger and Mali along the River Niger Basin, with the latest advances in spatial information technology, provides the pathway for efficient management of the basin. Advances in spatial information technology as a decision support tool not only helps in ecosystem recovery and the avoidance of conflicts, but it has the potentials to bring countries much closer through information exchange. Although GIS and remote sensing technology have only been around for not too long, they have emerged as valuable tools in natural resources management. Accordingly, geospatial information tools of GIS and remote sensing have already found widespread use in the areas of as forestry, water management as well as resource planning during environmental crisis [16-18]. The adoption of GIS and remote sensing as decision support tools for water resources reinforces the objectives of integrated resource management outlined in the United Nations document, Agenda 21 [16].

With the current approach to management compounded due to the depletion of available water resources and environmental resources within shared waters. The lack of information exchange that could be enhanced by geospatial data access extracts ecological costs from all players. Despite the current administrative setup of the Niger basin built on mutual co-operation, water projects were designed in the region with energy sharing agreements but without integrated management among some of the countries. In some instances, the unilateral pursuit of hydro projects without coordination and consent of neighbors created grave environmental impacts.

The Niger and Mali side of basin face enormous challenges at a time when environmental degradation and climate change are already taking their toll on the river [14]. In both nations, the river has come under enormous pressure with signs of degradation consisting of erosion of fish and wildlife stock and the decline of forests and water resources. In the last four decades, the region has also experienced series of droughts coupled with the widespread discharge of untreated effluents from upstream nations such as Mali into the river. By the time, the river passes through tributaries of other nations more untreated waste is offloaded into their waters. As a result, the downstream area water becomes so highly polluted that it erodes aquatic life and the livelihood of river fishing communities [13, 19].

Several areas along the Niger and Mali side of the region are quite vulnerable to high water stress due to human demand and the misuse of water resources. This is evident from the rate of water use among regions in Mali. In Table 1 the regional distribution of water in Mali shows that the combined exploitation of subterranean water for agriculture (cattle and irrigation) exceeds the volume required for the entire population. Existing records in the region has also pointed to the change in hydrographs of the Niger River, between the mean annual discharge of the humid and drought periods, the percentage of reductions varies from 40 through 60 percent. This has resulted in a modification of the Niger River at the Niamey section of the tributary in the republic of Niger [20, 21]. Other instances of change at Niamey occurred during 1970 to 1998, when the average flow of the Niger River in the city fell to $696 \mathrm{~m}^{3} / \mathrm{s}$. The sudden decline of the river flow 
contrasted heavily with the previous value of $1,035 \mathrm{~m}^{3} / \mathrm{s}$, during the period of 1944 to 1969 [22-24].

Table 1: Regional distribution of water use in Mali Exploitation of subterranean water estimated by region for 1989 in 000, cubic meters

\begin{tabular}{lcccc}
\hline Region & Population & Cattle & Irrigation & Total \\
\hline Kayes & 6,383 & 5,306 & 3,689 & 15,378 \\
Koulikoro & 7,921 & 6,080 & 3,586 & 17,557 \\
Sikasso & 9,258 & 7,821 & 4,277 & 21,356 \\
Segu & 8,298 & 4,494 & 3,370 & 16,162 \\
Mopti & 6,500 & 6,583 & 3,260 & 16,343 \\
Timbuctu & 2,496 & 4,996 & 1,879 & 9,371 \\
Gao & 2,188 & 3,178 & 1,361 & 6,727 \\
\hline
\end{tabular}

Source: [36]

As a remedy, development agencies such as the World Bank is already involved in a number of large-scale projects aimed at improving resources planning in the West African region. Within the last several years alone, the World Bank has embarked on a number of such projects in Guinea Bissau, Niger, Burkina Faso and Nigeria. However, most of these efforts tended to focus on national scale planning without a multinational and regional focus [16]. Applying the latest advances in geospatial information technologies (GIS and remote sensing) in the appraisal of the state of the basin's ecology along Mali and Niger is highly indispensable considering the move towards a multi-national watershed management by the nations of the basin. To confront the problems herein stated, some research questions with relevance to the paper have been posed. These include: Have there been any declines in the riverine ecosystem of the study area? What are the effects and what factors trigger the changes? What mitigation measures are in place for dealing with the problems?

\section{The Purpose and Organization of the Research}

This paper uses GIS and remote sensing in assessing the ecosystem decline in the Niger basin with emphasis on the Niger and Mali side of the river. The first objective of the paper is to develop a new framework for analyzing the declining health of riverine ecosystems while the second objective seeks a contribution to the literature. The third objective is to design a geo-spatial tool for riverine ecosystem management and impact analysis. The fourth objective is to measure the nature of change in riverine environments with the latest advances in geo-spatial information technologies and methods. In terms of methodology, the paper relies on primary data sources analyzed with descriptive statistics, GIS techniques and remote sensing. The sections in the paper consist of a review of the major environmental effects and factors associated with the problem as well as mitigation measures in Mali and Niger. The paper concludes with some recommendations.

\section{Background and Methods}

The Study Area: Mali and Niger Section of the River Niger Basin

The study location for this research shown in Figure 1.1 consists of Mali and Niger republic.

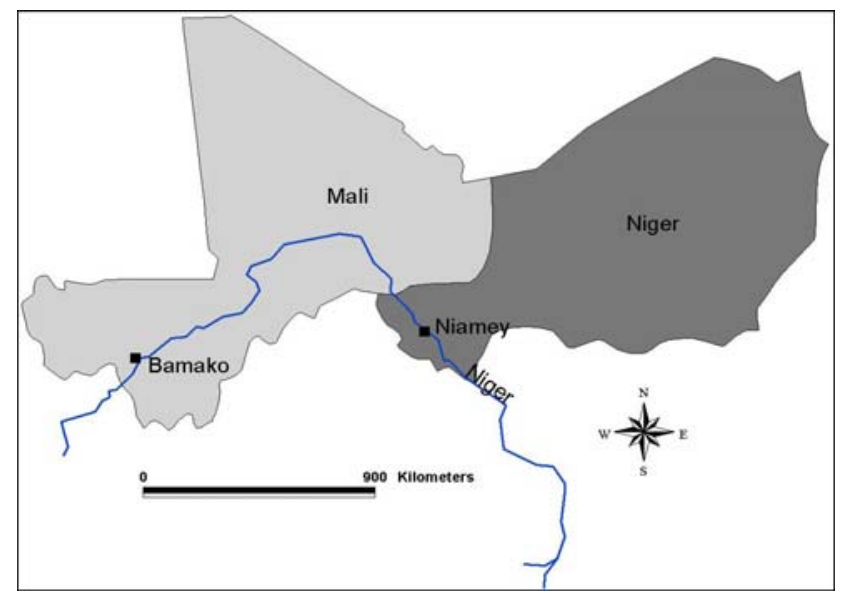

Figure 1.1: Map of the study area

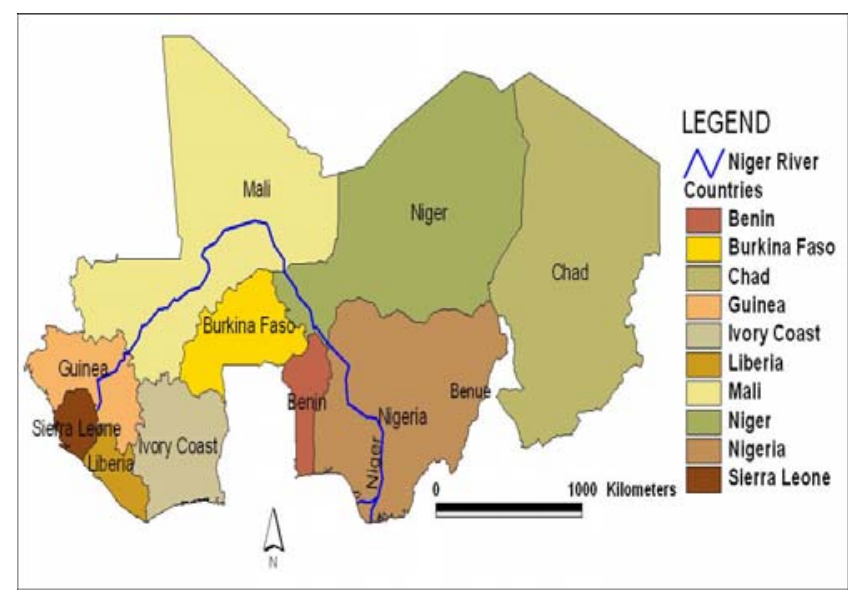

Figure 1.2: Map of the entire Niger River region

These are two landlocked nations in West Africa located along the border between the Sahara and SubSaharan regions in an area stretching over 2,506,700 km² with a combined population of 32.7 million. The population distribution for each country shows Niger with about 12.2 million people and Mali 10.5 million. The geographic coordinates for Niger are a longitude of $16^{\circ} \mathrm{N}$ and latitude of $8^{\circ} \mathrm{E}$ while Mali is located southwest of Algeria along the geographic coordinates of $17^{\circ} 0^{\prime} 0^{\prime \prime} \mathrm{N}$ $4^{\circ} 0^{\prime} 0^{\prime \prime} \mathrm{W}$. The climate of both nations is mainly hot and dry, with much area covered by desert. The major natural hazards consists of recurring droughts while the 
environmental problems in the area range from overgrazing; soil erosion; deforestation and loss of wildlife populations due to habitat destruction. With economic activity in the area largely confined to the riverine areas irrigated by the River Niger, the influence of humans in such activities coupled with population growth in the area have become a major purveyor of ecosystem change in an already fragile environment. Presently, the inhabitants of the area are predominantly involved in agriculture that depends on limited soil, water and declining vegetation. The pressures human activities are exerting on these environmental resources are unparalleled in the annals of the region as forest and woodland areas are disappearing at an alarming rate.

The River Niger identified in blue color in Figures 1.11.2 ranks as the principal and the most important river in West Africa. The Niger River is also the third longest river in Africa after the Nile and the Congo River. While the Niger River extends over an area measuring $4100 \mathrm{~km}$ [25], the basin's catchments area entirely situated between latitudes 4 and 17 north meridian 12 west and meridian 15 covers a total surface area of nearly $1,471,000 \mathrm{~km}^{2}$ shared among the nine countries proportionately listed in Table 2.1 .

Table 2.1: Water distribution rate - The distribution of surface catchment's area

\begin{tabular}{lc}
\hline Nations & $\begin{array}{c}\text { The percentage of surface } \\
\text { catchments }\end{array}$ \\
\hline Benin & 2.5 \\
Burkina Faso & 3.9 \\
Cameroun & 4.4 \\
Chad & 1.0 \\
Guinea & 4.6 \\
Ivory Coast & 1.2 \\
Mali* & 30 \\
Niger* & 23.8 \\
Nigeria & 28.3 \\
\hline
\end{tabular}

Source: [25]

From the Table see that the nations of Mali and Niger alone account for over half or 53.8 percent of the entire catchments area of the River Niger basin (Niger Basin Authority [14]. The River Niger as presented in Figure 1.2 takes its course from the Fouta Jallon Mountains in Guinea. The river flows at an altitude of about $800 \mathrm{~m}$ between the North East towards the periphery of the Sahara after crossing its own delta. The delta of the River Niger characterized by a large stream flow measured at $89,000 \mathrm{~km}^{2}$ dissipates an appreciable portion of its flow through absorption and evaporation. At the edge of the Sahara, the River Niger circles back creating an immense curve surging South East to the Gulf of Guinea which it arrives at after joining its main tributary, the Benue River $[14,26]$.
The River Niger and its tributaries boost of enormous biodiversity made up of mammals and numerous species of birds, plant resources, natural sites and parks [27]. The inland delta stands as one of the most significant wetlands of the continent with global importance and an outstanding biotope in the Sahel zone. The vast network of wetland ecosystems of the inland delta in Mali and the Atlantic Delta in Nigeria have been identified as important sanctuaries for biodiversity in the Niger River Basin [25, 28]. Because of the Niger River's role as lifeline of West Africa supporting biodiversity, the basin's fresh water wetlands are not only highly productive, they provide habitats for millions of resident and migratory birds in the area $[25,26]$. The human population living in the basin has been estimated at 110 million inhabitants [10, 37]. The population distribution in table 2.2 shows the Nigerian side of the basin as the most populous while Malian and Niger populations along the basin range from 4 and 2.7 million inhabitants respectively.

Table 2.2: Population of Nations along the Basin - The population distribution of the River Niger Basin

\begin{tabular}{lc}
\hline Nations & Population \\
\hline Benin & $1,950,000$ \\
Burkina Faso & $2,400,000$ \\
Cameroun & $2,100,000$ \\
Chad & 80,000 \\
Guinea & $2,500,000$ \\
Ivory Coast & 800,000 \\
Mali* & $4,000,000$ \\
Niger* & $2,700,000$ \\
Nigeria & $67,000,000$ \\
\hline
\end{tabular}

The region has high vulnerability to climatic risks and had been affected by severe droughts between 1963-1973, 1982-1985, and 1990-1991. During these periods, Niger Basin member nations including Mali and Niger experienced wide spread starvation. Each drought period amplified desertification, population explosion and unsustainable farming practices that led to overgrazing, soil erosion and deforestation [14]. Incessant drought and desertification which began three decades ago, made navigation and fishing impracticable in the region in some periods of the year. A case in point is in 1985 through 1990 when the river Niger essentially stopped flowing in Niamey, the capital of Niger [37]. Because of this continuous drop in its quantity, climate change and water experts' estimate that the volume of the basin has shrank by one third in the last thirty years alone. In the face of shrinking water supply in both Niger and Mali, competing land use practice involving irrigation shown in Table 2.3 and the expansion of cultivable areas with water thirsty crops in Table 2.4 has led to the proliferation of agrochemicals. During the 1990s, the average volume of fertilizer nutrients used among the farmers in both nations 
adjacent to the river basin was in the order of $5.4 \mathrm{~kg}$ for Mali and 0.8 for Niger. All these practices have resulted in high concentration of pollutants in the river which create further problems of riverine degradation in both countries.

Table 2.3: The size of irrigated area - Irrigated crop areas in West Africa (thousand hectares)

\begin{tabular}{lcccc}
\hline \multirow{2}{*}{ Nations } & \multicolumn{4}{c}{ Crop types } \\
\cline { 2 - 5 } & Wheat & Rice & Sugarcane & Vegetable \\
\hline \multirow{2}{*}{ Mali } & 4 & 213 & 4 & 3 \\
Niger & 2 & 30 & 6 & 12 \\
\hline
\end{tabular}

Table 2.4: The use of water for certain agricultural crops in the Region - Water Consumption by the thirstiest crops in the Niger Basin River

\begin{tabular}{|c|c|c|c|c|c|c|c|c|}
\hline \multirow{2}{*}{ Nations } & \multicolumn{2}{|c|}{ Rice } & \multicolumn{2}{|c|}{ Vegetable } & \multicolumn{2}{|c|}{ Sugarcane } & \multicolumn{2}{|c|}{ Wheat } \\
\hline & $\mathrm{Ha}$ & $\begin{array}{l}M / \\
m 3\end{array}$ & $\mathrm{Ha}$ & $\begin{array}{l}M / \\
m 3\end{array}$ & $\mathrm{Ha}$ & $\begin{array}{l}M / \\
m 3\end{array}$ & $\mathrm{Ha}$ & $\begin{array}{l}M / \\
m 3\end{array}$ \\
\hline Mali & 28,000 & 631 & 3,000 & 59 & 4,000 & 200 & 4,000 & 112 \\
\hline Niger & 30,000 & 1,050 & 12,000 & 278 & 6,000 & 493 & 3,000 & 72 \\
\hline Total & 58,800 & 1,681 & 15,000 & 337 & 10,000 & 693 & 7,000 & 184 \\
\hline
\end{tabular}

$\mathrm{M}=$ Millions

Table 2.5: Projected water demand - Water demand forecasts for two West African Countries

\begin{tabular}{lcccc}
\hline \multirow{2}{*}{$\begin{array}{l}\text { Selected } \\
\text { Nations }\end{array}$} & $\begin{array}{c}\text { Irrigated } \\
\text { Cereal } \\
\text { Area }\end{array}$ & $\begin{array}{c}\text { Primary } \\
\text { Water } \\
\text { Supply }\end{array}$ & $\begin{array}{c}\text { Rain Fed } \\
\text { Cereal } \\
\text { Area }\end{array}$ & $\begin{array}{c}\text { Potential } \\
\text { Utilizable } \\
\text { Water }\end{array}$ \\
\cline { 2 - 5 } & $\begin{array}{c}\text { Million } \\
\text { ha }\end{array}$ & Km3 & $\begin{array}{c}\text { Million } \\
\text { ha }\end{array}$ & $\begin{array}{c}\text { Resource } \\
\text { km3 }\end{array}$ \\
\hline Mali & & & & \\
\hline 1995 & 0.03 & 0.7 & 6.49 & 28.2 \\
2025 & 0.05 & 1.3 & 10.83 & \\
Increase (\%) & 66 & 90 & 67 & \\
\hline Niger & & & & \\
\hline 1995 & 1.06 & 5.0 & 16.75 & 158.3 \\
2025 & 1.43 & 7.6 & 26.41 & \\
Increase (\%) & 35 & 53 & 58 & \\
\hline
\end{tabular}

In the Urban areas, residues from industrial and domestic activities seep into the river usually through open channels without prior treatment. For example in the Malian capital of Bamako situated on the Bank of the Niger River, nearly all the cities commercial and residential effluents drain into the river untreated [13]
[19]. With the $64 \%$ of the nation's industries concentrated in the city, eight of those entities discharge about $2,200 \mathrm{~m}^{3}$ of wastewater with chemical pollutants, heavy metals, and organic pollutants. The annual volume of these pollutants estimated at $770,000 \mathrm{~m}^{3}$ empty directly into the waters of the Niger River [29]. By the time the river water gets to Burkina Faso, the waters are heavily polluted and undrinkable [13, 19]. In the year 2000 only $52 \%$ of the population in Niger republic had access to safe drinking water [30]. Considering the projected water demands in the both nations between 1995 through 2025 as shown in Table 2.5, the continuous rise in water demands due to human pressures stands as a daunting task for resource managers in meeting the needs of competing users.

\section{Methods Used}

This paper stresses a mix scale approach involving the integration of primary data provided through government sources and data bases from other organizations. The raw spatial data and satellite images used in the research were procured through The United States National Aeronautical and Space Administration (NASA) and other organizations.

\section{Data Acquisition}

The first step involves the identification of the variables needed to assess environmental change and decline at regional level. The variables consist of socioeconomic and environmental information, including amount of cropland, human settlement, water bodies, forest types, and population, (See Tables 1.1 and 3).

Table 3: Results of the classified images for 1987 and 2000

\begin{tabular}{lccc}
\hline Classes & $\begin{array}{c}\text { Area (ha) } \\
\text { in 1987 }\end{array}$ & $\begin{array}{c}\text { Area (ha) in } \\
2000\end{array}$ & $\begin{array}{c}\text { \% Change } \\
(1987-2000)\end{array}$ \\
\hline Water & 158,702 & 138,010 & -13.04 \\
Shrubs & 620,042 & 471,026 & -24.03 \\
Settlement & 53,290 & 127,859 & 140.00 \\
Plateau & 406,552 & 220,240 & -46.00 \\
Surface & & & \\
Plateau & 233,175 & 255,065 & 9.39 \\
Vegetation & & & \\
Agricultural & 107,996 & 223,988 & 107.40 \\
Fields & & 243,679 & 72.00 \\
Bare Areas & 200,110 & 349 & \\
\hline
\end{tabular}

This process continued with the design of data matrices for the variables covering the various periods from 1987 and 2000 and beyond. In addition, to the design stage, access to databases and abstracts that are presently available within the Federal archives in Mali and Niger, The United States National Aeronautical and Space 
Agency (NASA) and host of other organizations helped facilitate the search process. The spatial data acquired from NASA consists of two Satellite images covering the nations of Niger and Mali for the separate periods of 1986 through 2000 and some information from the University of Maryland free online images.

\section{Geo Spatial Data Processing and Analysis}

For the countries of Niger and Mali multi-seasonal images were obtained for the study. The images that were assembled for Niger and Mali include Landsat Thematic Mapper (TM) and Enhanced Thematic Mapper (ETM+) data pair of 13 October 1987 and 23 September 1999; 18 November 1986 and 12 October 2000, and 12 November 1985 and 20 October 2000. The path and rows of the scenes used in the spatial coverage of the same areas of Mali and Niger were: (193, 051, (193, and 051), (194, 048), (194, 050) and $(195,049)$. All the images were processed using ERDAS IMAGINE 8.7 image processing software. The images for Mali and Niger were imported into ERDAS as a single band using ERDAS native file format GEOTIFF. All the bands for the two countries were then later grouped together by employing ERDAS Layer Stack modules. This was followed by geometric correction of the images to remove, haze, scan-lines and speckles. The scenes were later mosaicked using ERDAS Mosaic Tool. Image matching techniques were applied on all the images in order to achieve uniform color on all the images. A linear stretch enhancement technique was performed on all the images, and later subset using ERDAS Area of Interest Tool (AOI) to emphasize the study area. The spatial data was later geo-linked to allow for the subset of both images to the study area. Finally, image categorization was also performed using unsupervised classification techniques. The remaining procedure involves spatial analysis and output (maps-tables-text) covering the study period with ARCVIEW GIS. The spatial units of analysis consisted of the two nations located in the Niger River basin (Figure 1.1). Outputs for the two countries were mapped and compared across time. This process helped show the extent of temporal-spatial evolution of ecological decline induced by human activities along the Niger River basin ecosystem.

\section{Results}

This section presents the results of the data analysis consisting of an initial synopsis of the descriptive statistics and geospatial analysis of change. Later, it highlights the factors associated with ecological decline in the study location and the mitigation measures to address the problems.

Temporal Spatial Analysis of Environmental Change in Niger and Mali

The results of 1987 and 2000 classified images are shown in Figures 2.1 - 2.2 and Table 3. The accuracy of the results was compared with the available information on the area. For the purposes of identifying the themes on the legend, the blue color describes water bodies of the Niger River flowing in the study area. The yellow color represents the areas covered by human settlement while the white color stands for bare areas. The red color on the other hand displays the size of plateau vegetation, dark green and light color stand for the shrubs and agricultural fields respectively. The plateau surface of the area is characterized by the purple color.

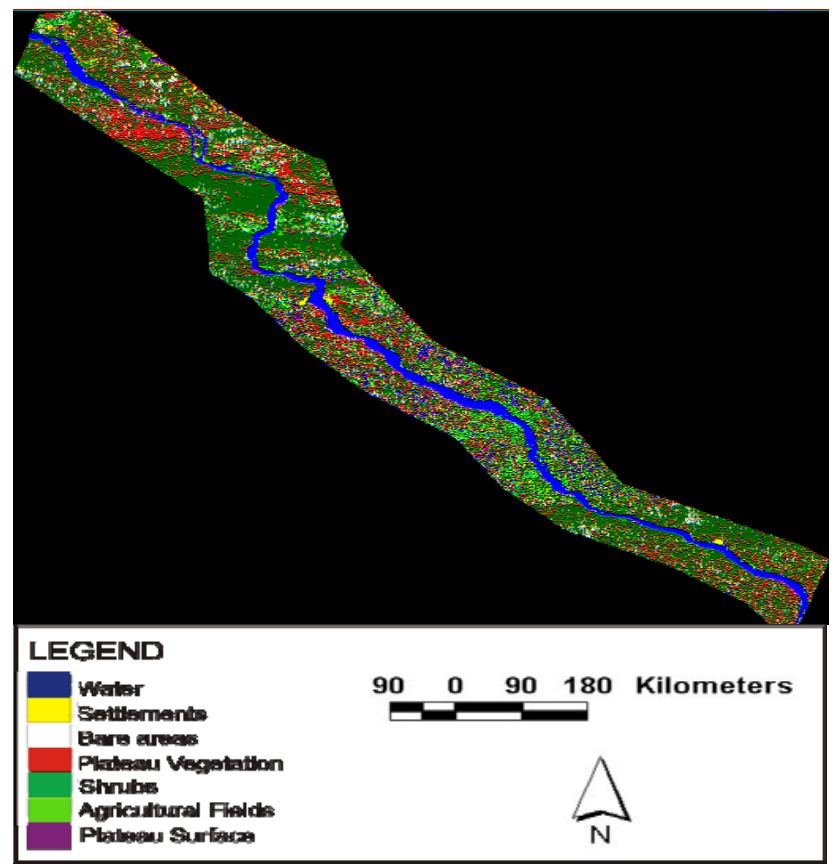

Figure 2.1: Classified Image of Landsat TM, 13 October 1987

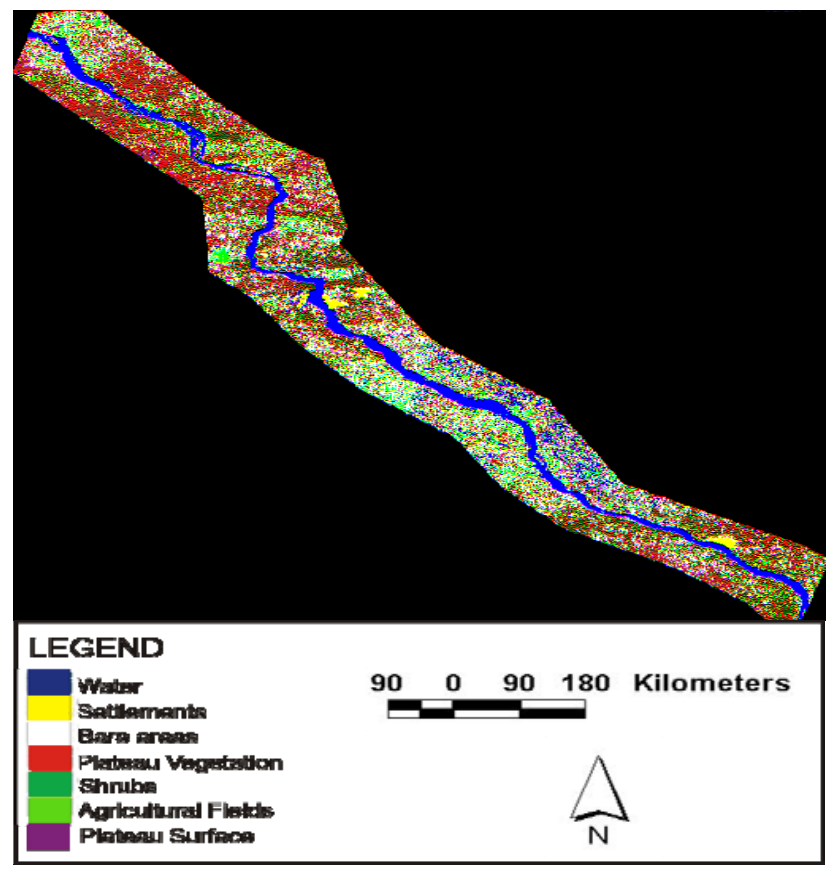

Figure 2.2: Classified Image of Landsat TM, 20 October 2000 
In Figures 2.1 - 2.2, and Table 3, see that water bodies experienced slight decline from 158,702 to 138,010 hectares. Shrubs and plateau surface also posted a decline from an initial estimate of 620,042 hectares in 1987 to 471,026 hectares for shrubs; and from 406,552 hectares in 1987 to 220,240 hectares for plateau surface. This represents an overall decrease of 24.03 and 46 percent respectively. While shrubs, water bodies and plateau surfaces declined, areas under settlement, agricultural fields and bare areas were increasing as well. For instance, between 1987 and 2000, agricultural activities increased from 107,996 hectares to 223,988 hectares representing a change of 107.40 percent. Plateau vegetation also posted a slight change from 233,175 hectares in 1987 to 255,065 hectares in 2000, an increase of 9.39 hectares. Human settlement had the highest increase in the area. For example, from the initial estimate of 53,290 hectares in 1987, it doubled to 127,859 hectares in 2000 representing an overall increase of 140 percent. The overall decline of the water bodies, development of bare areas and the decrease of the prime vegetation in the area might be attributed to the seasonal changes in the rainfall patterns and increase in population from the 1970s to $2000[17,18]$.

From both the visual and spatial display of the two satellite images in figures 2.1 and 2.2, see that the distribution of the river flow and its network represented by blue color in both nations appeared much thicker and pronounced during the period of 1987 . These visibly distinct physical features began fading as we approached the 13 years period stretching from 1987 to the year 2000 . At the same time, notice how the images of human settlements that appeared clustered in minor patches on the middle portion of the map in 1987 gradually picked up steam and intensified with more concentration of human activities in some of the areas under analysis. The spatial evolution of the size of agricultural land areas and bare surface areas shows both features blossomed exceedingly with numerous activities along the shores of River Niger.

\section{The Impacts of Dams}

The construction of dams displayed in Figure 3 within the Malian and Niger coasts of Niger River basin have brought with it adverse consequences on water input downstream of the dams and accordingly on fish abundance and diversity [31]. Such activity of the dams in the area has also been associated with interference on the natural dynamics of the river. In Mali for instance, the functioning of Markala and Selengue dams increased the effects of drought by lowering river flows. This resulted in the annual loss of 5000 metric tons in total fish catches in the central delta [32, 33]. The dams also affected upstream fish production by hindering longitudinal movement of fish. More so, Nigeria with about 1.6 million hectares of irrigated land, river transport installations and urban water supply, fears today that the construction of dam projects upstream such as the Kandadji dam projects in Niger and Toussa Dam in Mali would lead to reduced flow to its Nigerian part. On several occasions the Nigerian authorities expressed their concerns on dam construction upstream on the River Niger that would involve the reduction of more than 10 percent in the volume of its annual inflow [33].

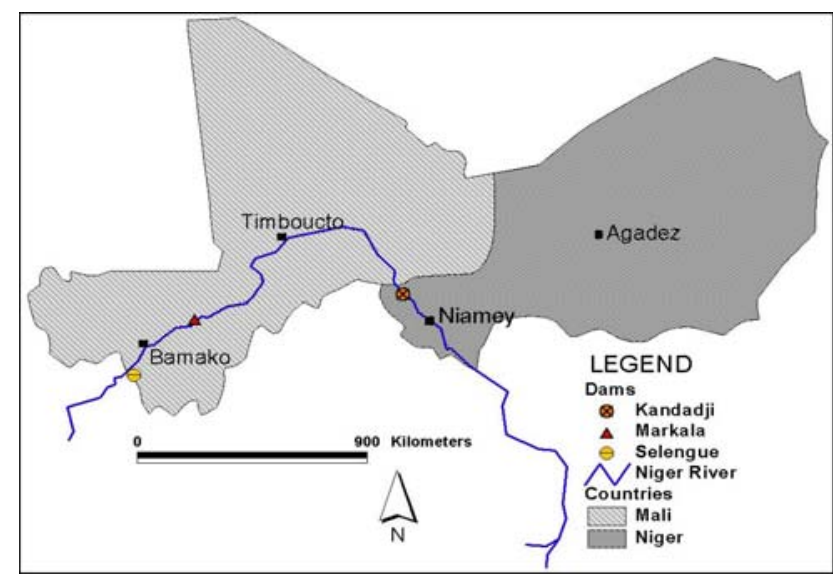

Figure 3: Location of Dams in Mali and Niger Republic Associated With Ecological Change

Further evidence along the Kandadji dam in the republic of Niger suggests that western Niger is likely to experience more frequent periods of drought with larger climatic variations, followed by growing trend in ambient temperatures and an increase in evaporation. In such conditions, the riverine ecosystem of the Niger basin risks a complete collapse of its carrying capacity, with grave environmental and socio-economic consequences in the region [22]. Already, the rich biological diversity characteristic of the river zone has been experiencing gradual decline for quite some time. Several rare species in the river such as the West African manatee and the hippopotamus risk extinction in spite of the preservation measures taken by decision makers through policy and strategies.

\section{Factors Associated with Ecological Decline}

This section of the paper briefly identifies some of the factors contributing to the ongoing decline in the river ecosystem of the River Niger basin along the coasts of Niger and Mali. Just as indicated in the other sections of this research, the current ecological problems faced in the River basin of the two countries under analysis do not operate in a vacuum due to several variables. The driving forces of degradation ranging from policy to climate change are not only multi-sectoral in nature, but they have been partly associated with the decline of the basin's riverine ecosystem in recent years on the areas of land and water resources. With the lack of space and the requirements of page limits, we limit our analysis to a sketchy outline of the main factors fuelling ecosystem change in the basin under the themes listed below. The factors include:

1. Policy: Inadequate coordination of land and water management frameworks

2. Land use: Continued degradation of land, water, and renewable resources 
3. Data Gap: Insufficient data for good management practice/ decision support

4. Development: Cumulative degradation from hydropower sector due to construction of dams

5. Inaction: Interest groups directly linked with degradation not doing enough to reverse the trend

6. Population: Growth in population contributing to environmental decline

7. Climatic Change: Variability in climate affecting the basin's ecosystem

\section{Restoration Initiatives}

The member states of the River Niger basin have undertaken various initiatives over the years aimed at minimizing the declining levels of the ecosystem especially on the Niger and Mali side of the river [14]. The programs comprise of the different projects for reversing degradation in the Niger River basin, cooperation agreements and the design of land cover monitoring program.

Project for Reversing Degradation in the Niger River Basin

The projects cover the sustainable action plan (SDAP) and the global environmental fund (GEF) initiatives. While the environmental objectives are to reduce and prevent trans-boundary water related environmental degradation. There is also an emphasis on preventing land degradation and protection of biodiversity of global significance through sustainable and cooperative integrated management of the basin among member states. Attaining these objectives require improvements in a number of areas such as existing capacity, decision making and public involvement in the basin's decision making process that is applicable to both Niger and Mali.

\section{Sustainable Development Action Plan (SDAP)}

Recognizing the common concerns of the riparian countries to address the basin's issues, the Niger basin countries are putting together a sustainable development action plan (SDAP) for the basin. With the support of the World Bank, the program focuses on the broader issues of multi sectoral sustainable development of the basin. The SDAP will involve all possible sectors including those whose activities trigger environmental externalities. Part of the initiative is intended to ensure the sustainable development of the basin's land and water resources, including the protection of its unique dry-lands environment and associated biodiversity that are vulnerable in Mali and Niger.

\section{Global Environment Fund (GEF)}

The global environment fund (GEF) strategic action program (SAP) focuses on managing the basin's environment. The GEF/SAP is identifying and prioritizing water related environmental issues and sectors across the River Niger Basin member states as well as developing a framework for environmental management of all development activities in the basin and the two Sahelian countries of Niger and Mali. The GEF project supports strengthened regional and national decision-making capacity by providing a better understanding of the sectoral issues responsible for land and water degradation, and a mechanism to manage these trans-boundary issues in a more inclusive decision making process. Elements of the initiatives, center on ensuring the protection of the river system through an integrated management of the basin's resources in order to mitigate the causes and effects of desertification as well.

\section{Cooperation Agreements}

The leaders in Niger republic have been quite active in interstate cooperation agreements involving various international organizations such as the Niger Basin authority (NBA) and the Authority for the Liptako-Guourma Area, (ALG) in the resource management of the Niger River. In addition, cooperation agreements exist between Niger and Mali, Niger and Nigeria, concerning water resource management. The elements of the agreements reaffirm the transfer of management responsibilities from the state authorities to local communities and the private sector. The intent is to enhance local involvement in river ecosystem recovery plans, conservation as well as the development and integration of fish farming in irrigated areas under the aegis of community management.

\section{Geospatial Monitoring Land Use and Land Cover Changes}

The EROS Data Center operating through its partnership with the AGRHYMET Regional Center in Niamey, Niger, is designing an approach for geospatial analysis and the evaluation of resources utilization by assessing changes in land use and land cover in the region. The project aims to classify land resources through time series data and with present day satellite information and ground data in three periods of 1965, 1985 and 2000. Proponents of the program are interested in gaining sound knowledge of the bio-geoclimatic and socioeconomic variables fueling ecological decline. In light of that, EROS and AGRHYMET are also working through the Sahel Institute in Bamako, Mali, to integrate factors associated with socioeconomic issues and policy matters associated with the catalysts of ecological change in the area. To fulfill the terms of this project, EROS is investing heavily in training sessions focusing on monitoring of land resources using remote sensing technology, geospatial data analysis and management for the purposes of policy.

\section{Discussion}

The results not only reveal the pace at which human influences are affecting the River Niger basin, but it points 
to a rapidly growing ecological decline. In an environmental and hydrological analysis of the trends in the basin using a set of ecological and socioeconomic indicators, the study found that the River Niger ecosystem on the upper Niger states of Mali and Niger to be under stress. The Malian and Niger's side of the basin seems to be under tremendous desolation that is threatening the life support of the region due to several decades of persistent drought, environmental degradation and population explosion. While the extent of ecological change showed some variations across time and space, these changes are associated with socio-economic and environmental variables and host of other factors connected to natural and anthropocentric activities. Over all, the results point to a decline in water bodies, the loss of areas covered by shrubs, decline in plateau surface and some increase in human settlement, plateau vegetation, agricultural fields and major rise in bare areas. Some of these changes pose a major threat to the areas in the upper sides of Niger and Mali due to the potentials for drought and desertification. Already in the Niger side as shown in Table 4, degradation of forest area seemed quite rampant with consumption exceeding production and the regenerative capacity of forests and woodland areas in the country.

Table 4: Balance of forest productivity and wood energy consumption for regions in Niger - Forest consumption in 1998

\begin{tabular}{lccc}
\hline Cities & Production & Consumption & Balance \\
\hline Agadez & 1,800 & 91,980 & $-90,180$ \\
Diffa & 21,517 & 55,003 & $-33,486$ \\
Dosso & 409,770 & 306,600 & 103,170 \\
Maradi & 90,000 & 398,815 & $-308,815$ \\
Tahoua & 27,672 & 485,000 & $-457,328$ \\
Tillabéry & 300,000 & 600,000 & $-300,000$ \\
Zinder & 60,000 & 200,000 & $-140,000$ \\
Niamey & & & \\
Urban & 0 & 156,000 & $-156,000$ \\
Community & & & \\
\hline Total & 910,759 & $2,293,398$ & $-1,382,639$ \\
\hline
\end{tabular}

Source: [36]

Bearing in mind the extent of increases in agricultural fields and human settlements in the foregoing analysis, the pace of these changes in Mali are worthy of mention here. In the case of southern Mali, for instance, part of the root causes of degradation comes from the intensification of farming through the cultivation of cotton and population growth even though there is a major awareness among farmers about inherent linkages between current production systems and unsustainability. The environmental effects of production increases during the closing decades of the 1990s seemed overlooked given the economic returns that accrue cotton production and the success of cotton producing areas in rural development regardless of the huge ecological costs associated with such farming activities [34]. In the Bamako district of Mali where there is an average of 2,460 inhabitants per square kilometer, climatic and degradation factors particularly, water decline appear possibly linked to such uneven distribution across space. The urbanization rate not only intensifies in those settings, but given the projected growth of the city estimated at 2.6 million inhabitants in 2020, pressure on the riverine ecosystem of the Niger River in that country will likely persist.

Turing to large irrigation projects in both Niger and Mali and impacts, it is evident that most dams in the area designed to impound water have the potentials to cause major environmental disturbances resulting from severe changes in hydrology of the river basins. Reducing the river flow under this condition changes flood plain land use and ecology and it can cause salt water incursion into the river and to ground water of adjacent lands. Consequently, large-scale water infrastructure projects that trigger the degradation of natural areas through flooding are threatening people's livelihood and access to water and fishing activities. Habitat alterations caused by dams are also degrading the rich tapestry of the river Niger ecosystem [35]. It has been associated with altering the flow and sediment regimes of the rivers in the basin in addition to considerably fragmenting aquatic habitats. Irrigated floodplain agriculture known for destroying productive habitat for fishery, livestock, and wildlife also results in the discharge of pollutants into the rivers. This will not only threaten the carrying capacity of an already fragile ecosystem, but it poses enormous challenges for both environmental and natural resource managers and policy makers in both countries of the region if not confronted with the urgency.

Considering the intense ecosystem stress inflicted on the riverine ecosystem of the River Niger by human activities and natural forces emanating from upstream and downstream nations. Assessing the influence of human activities on the basin with the latest advances in spatial information technology as a decision support tool not only helps in averting conflicts, but it has the potentials to improve the ecosystem management of the river. With cooperation among the states quite often compounded due to the intense degradation of riverine resources and the unilateral pursuit of hydro projects. The practical use of a mix scale approach involving the use of GIS and remote sensing in analyzing environmental and hydrological changes associated with riverine ecosystem decline stand as an update to current literature on ecological change of the River Niger region of West Africa particularly the Niger and Malian sides of the basin. Judging from the minor efforts in the past to examine environmental problems confronting the River Niger basin, spatial technology as used in this paper has fulfilled a useful purpose in mapping hydrological and environmental data by showing some of the changes that resulted in acute 
declines brought by human activities in the two countries. The paper also provides an effective road map towards the design of geospatial decision-support tools that are essential in the management of riverine ecosystems along West Africa.

\section{Recommendations}

To deal with the concerns raised in the research, six recommendations are presented.

\section{Restore Degraded Habitats}

Several decades of intense human activities along the basin of the two countries has ravaged the riverine ecosystem of the river Niger. The gravity of the ecosystem decline requires immediate restoration in order to ensure speedy recovery of the natural systems. The restoration of the Niger River ecosystem in both Mali and Niger republic should start in the river basin with best management practices that encourage green (vegetative) cover and the reduction of soil erosion. The restoration of the floodplains wetland pastureland' is also invaluable elements in optimizing the river's productivity.

\section{Keep Economic Activities in Sync with Nature}

Extreme anthropogenic utilization of the river flood plain in the area of agriculture and hydropower is susceptible to regional phases of flood and drought. Much can be gained in both nations by adopting indigenous resource use models that encourage speedy recovery from ecological problems by keeping economic activities and development projects in sync with the carrying capacity of the basin's ecosystem. Essential, to keeping economic activities in sync with nature will be by educating diverse communities including decision makers about natural functions performed by the Niger River.

\section{Strengthen Regional Cooperation}

With trans-boundary activities in the River basin partly contributing to environmental decline in the region, the nations of the basin including those of Niger and Mali should continue working towards the adoption of viable regional framework built on cooperation. This will help to quicken trans-boundary monitoring of the ecological threats and the speedy recovery of the Niger River ecosystem.

\section{Promulgate Effective Regulations}

Policies are the most common instruments used to address riverine pollution wherever they occur due to their simplicity and ability to satisfy the interests of various stakeholders. Because most regulators in the region just as in other developing nations lack the resources to enforce regulations, the paper suggests that more effective laws be promulgated to stem the tide of ecosystem decline currently ravaging the waters of the Niger. This will help in strengthening the existing regulations.

\section{Encourage Government Investment in Water Treatment}

Government investments in Mali and Niger can be quite effective in reducing pollution along the tributaries of River Niger basin in both countries. With widespread seepage of wastewater effluents from upstream to downstream, the construction of wastewater treatment facilities can improve the quality of water in the region's coastal areas. Initiatives of this sort can also involve the imposition of moratorium on the dumping of untreated wastes along the riverbanks by designating vulnerable hot spots of pollution as protected areas pending recovery.

\section{Support Coordinated Water Management}

The riparian countries of the Niger River such as Mali and Niger constantly experience recurrent climatic variability, population pressures and the problem of unilateral pursuit of hydropower development that affect the level of the river. In the areas of agricultural production, hydropower and environmental protection, several problems can be solved through coordinated management of the river. Synchronized management of the water resources among the member states will make it possible to take full advantage of the ecological assets in way that benefits the riverbank communities.

\section{Conclusions}

This paper has presented an assessment of ecosystem decline along the River Niger basin of West Africa particularly the Mali and Niger side by using GIS and remote sensing tools in the analysis. The paper outlined an overview of the issues in the literature and the ecological problems confronting the region. This was followed with the outline of the environmental trends in the River Niger Basin of West Africa with some emphasis of the attributes of Niger Basin region, the essence of GIS and remote sensing based approach, the analysis of environmental and hydrological change and the current initiatives in mitigating the problem and the factors fueling it. Notwithstanding the gravity of the trends in the region and continued negation of the problem, there has not been any major effort among decision makers aimed at analyzing ecosystem decline of the River Niger region of Mali and Niger by using geospatial information systems.

Considering the growing pressures mounted by human activities in the region, the results from the data analysis reveal that the study area experienced some significant changes particularly along the riverine ecology of River Niger and the plateau surfaces. Other changes in the area include those on water bodies and the areas covered by shrubs. These changes are attributed to socioeconomic and environmental variables and host of other factors. The results point to a decline in water bodies, plateau surface, shrubs, and increase in human settlement, 
agricultural intensification as well as the potentials of drought and desertification due to increases in bare surfaces in both Niger and Mali. Apart from the declines in plateau surface and shrubs, there were some minor gain in plateau vegetation in Niger and Mali.

Other interesting findings touch on the potentials for population growth due to the expansion of human settlements as well as the dangers posed by dams. The proliferations of dams in the region have the potentials to cause major environmental disturbances resulting from changes in hydrology and limnology of the river basins. This will not only threaten the carrying capacity of an already fragile ecosystem, but it poses enormous challenges for environmental and water managers and policy makers in the region if not confronted with dispatch. To deal with these problems, the paper offers some recommendations as part of the strategies for the region. The recommendations range from habitat restoration to coordinated water management.

The analysis of ecosystem decline on the Niger River Basin portions of Mali and Niger using GIS and remote sensing coupled with the appraisal of environmental and hydrological changes showed some valuable results. GIS technology as often used by scientists for mapping of spatial data stands as an effective tool for monitoring the decline of complex tropical riverne ecosystems such as the Niger River basin. This is essential for the provision of information regarding the extent of stress facing the River Niger Basin ecosystem. Using remotely sensed satellite imagery and GIS modeling, quickened the analysis of the geographic diffusion of riverine ecological decline involving land use and land cover classification, made up of plateau surface, shrubs, hydrology and human settlement expansions threatening the River Niger Basin. The paper serves as a valuable tool for enhancing decision support systems that are necessary in sustaining the basins' ecological health and recovery.

\section{References}

1. Elhance, A.: Hydropolitics: Grounds For Despair, Reasons for Hope: International Negotiation, 2000, 5:2, 201-222.

2. Wichlens, D.: Cooperation regarding water and other resources will enhance economic development in Egypt, Sudan, Ethiopia and Eritrea. Water Resources Development. 2003 (December), 19:4:525-552.

3. Ashok, S.: The Nile River Basin Initiatives Too Many Cooks, Too Little Broth. SAIS Review, 2002, (summer, fall) 293-308.

4. Dinar, S.: Water Security, Conflict and Cooperation. SAIS Review. 2002 (summer, fall) 229-253.

5. Williams, P.: Nile cooperation through Hydropolitik feature review. Third World Quarterly, 2002, 23:6:1189-1196.

6. Collins, R.: Waters of the Nile: Hydropolitics and the Jonglei Canal 1900-1988. Oxford: Clarendon Press UK, 1990.
7. Singh, A.: Assessing Environmental Conditions of the Major River Basins in Africa as Surrogates for Watershed Health. Ecosystem Health, 1999 (December), 5: 4: 265-267.

8. Charrier, B.: Water Conflict, Resolution and Environmental Sustainability in the Middle East. Arid Lands, 1998 (fall/winter), 44: 1-10.

9. Associated Press. African Heads of State meet at Niger River Basin Conference. AP, 2004 (April 27), 1-2.

10. Bryant, L.: African leaders sign declaration on Niger River Basin. The Epoch Times, 2004, 1-2.

11. Hobbs, J.: Sustainability: Do water wars still loom in Africa? Inter Press Service, 2004 (May 15), 1-6.

12. Niger Basin Authority (NBA). Development of water resources and reforestation of the degraded zones of the River Niger Basin. NBA Technical Directorate. Niamey: Niger, 2003.

13. United Nations Office. Niger River Action Plans, But the River is Shrinking Central African. Regional Program for the Environment CARPE Congo Basin News. UN Office for Coordinating Humanitarian Affairs, 2004.

14. Niger Basin Authority (NBA). NBA Information. Niamey, Niger. http://www.abn .ne/webeng/nbainfo/ nbainfo3, 24/2/2006

15. Laboo, R.: The spread of Biophalaria pfeifferi in the Niger River Valley, Niger Annals of Tropical Medicine, 2003, 97:2: 209-212

16. Asante K.: Niger Basins Reservoirs, Department of Civil Engineering, University of Texas, Austin. http://www.ce.utexas.edu/prof/maidment/grad/asnte /net/nigerweb.htm 2/24/ 2006.

17. Manu, A.; Twumasi, Yaw A.; Coleman, T. L.; JeanBaptiste, T. S.: Investigation of the impact of urban sprawl in three Sahelian cities using remotely sensed information. In Proceedings of the IEEE International Geoscience and Remote Sensing Symposium (IGARSS) Conference (on CD ROM). July 21-25. Toulouse, France, 2003, vol. II. pp. 988-990.

18. Twumasi, Y. A.; Manu, A.; Coleman, T. L.; Maiga, I. A.: The Impact of Urban Growth and Long-term Climatic Variations on the Sustainable Development of the City of Niamey, Niger. In Proceedings of the IEEE International Geoscience and Remote Sensing Symposium (IGARSS) Conference (on CD ROM). July25-29. Seoul, South Korea, vol.II., pp. 15001503, 2005.

19. IRIN. River Niger Action Planned But River Is Shrinking. United Nations Office of Humanitarian Affairs, 2004.

20. 20. Inter Governmental Panel on Climate Change. (IPCC). Climate Change 2001: Working Paper 11: Impacts, Adaptations and Vulnerability. Geneva, Switzerland, 2001.

21. Cornway, D.: Understanding the Hydrological Impacts of Land use Change. Updates, 2001, 1: 1-4

22. Hassane, K.: Assessment of the Environmental Impacts of The Kandagi Dam Project: An energy choice identified under the national energy and 
sustainable development program AJEAM- RAGEE, 2003, 5:46-54.

23. High Commission for the Kandadji Dam. Phase 2 Feasibility Study Volume IV, Interim Report, Prime Minister's Office, Niamey, 2000.

24. United Nations Economic Commission for Africa (UNECA). Upper Niger Basin recorded lowest flow in Niger, March 2003.

25. Davis, T.: Agricultural Water Use and River Basin Conservation. DJ Environmental UK/World Wildlife Fund (WWF), WWF International, Gland, Switzerland, 2003.

26. Maidment, D.: Water Balance of the River Niger Basin in West Africa. Paper presented at The $17^{\text {th }}$ Annual ESRI-USER Conference, San Diego, CA, 1997 (July).

27. Mockrin, M.; Thieme. M.: Inner Niger Delta Flooded Savanna. World Wildlife Fund (WWF). WWF International, Gland Switzerland. 2001.

28. Bourn, D.: Biodiversity Focal Points for Resource Management in the West African Niger Basin. Environmental Research Group. Oxford Limited, 1992.

29. Diara, A.: Pollution in Mali. In Proceedings of the United Nations Environment Program (UNEP) Meeting, Bamako, Mali, 2000.

30. Ada, L.: Niger Progress towards Environmental Sustainability. United Nation Development Program, 2003.

31. Petts, G.: Management of Fish Population in Large Rivers: A review of Tools and Models. In DP Dodge Ed. Proceedings of the International Rivers and Civilization Symposium, 1989.

32. Lae, R.: Impact Des Barages Sur Les Percheris Du Delta- Central Du Niger. Cashiers d'Agricultures. 1992, 2:14-21

33. Lae, R.: Review of the Present State of Knowledge of Environment, Fish Stocks and Fisheries of the River Niger West Africa. Paper Presented at The $2^{\text {nd }}$ Large River Symposium (LARS). Pnom Penh. 2003 (February).

34. Moseley, W.: Environmental Degradation in Mali: Poor Farmers or Profit Department of Geography Macalester College St Paul, MN, 2004.
35. World Wildlife Fund (WWF). The River Niger, River of Rivers, Living Waters. WWF International Gland, Switzerland, 1986.

36. N’Djim, H.: Doubia By. Case Study: Mali Population and Water Issues Ministere du Development Rural et del Environnement in Water and Population Dynamics: Case Studies Policy 37 Implications eds. Alex de Sherbinin and Victoria Domkpa. AAS and IUCN, 1998

37. Olliver, C.: African Heads of State Meet at Niger Basin River Conference. Associated Press (AP), 2004, 1-2.

38. Milich, L.: Openness, Sustainability, and Public Participation in Transboundary River Basin Institutions. Arid Lands, 1998 (Fall/Winter). 44: 1-8

39. Kaya, I: The Euphrates-Tigris Basin: An overview and opportunities for cooperation under international law. Arid Lands, 1998, 44: 1-12.

40. Hebard, E.: Toward Jointly Managing a Transboundary Aquifer: Creating a binational dialogue through community participation and education. Arid Lands, 1998, 44: 1-12.

41. Barkin, D.; Pailles, C.: Water as an instrument for sustaibale regional development. Arid Lands, 1998, 44: $1-12$

42. Burchi, S.; Spreij, M.: Institutions for International Fresh Water. UNESCO IHP WWAP, Technical documents in hydrology, PCCP Series 3. 2003.

43. EROS Data Center, June 5-6, Sioux Falls, South Dakota, USA. (Online.) http://www.ncgia.ucsb.edu/ conf/landuse97. 1997.

44. National Center for Eros. Monitoring land use and land cover in the Sahel EROS SIOUX Fall SD. 2006.

45. Niase, M.: Climate induced water conflicts risks in West Africa: Recognizing and coping with increasing climate impacts on shared watercourses. Human security and climate change: An international workshop, Holmen Fjord Hotel, Asker, Near Oslo Norway, 2005 (21-23 June).

46. Niger Basin Authority NBA. Development of water resources and restoration of the degraded land of the Niger Basin. Niamey, Niger, Technical directorate operations division, Niamey Niger Republic, 2005.

47. CNED. Natural Environmental Council $f$ or Sustainable. Prime Minister's office, Niamey Niger. 1998. 